\title{
ACAROLOGY
}

\section{Brevipalpus Mites Donnadieu (Prostigmata: Tenuipalpidae) Associated with Ornamental Plants in Distrito Federal, Brazil}

\author{
Letícia C. Miranda ${ }^{1}$, Denise Návia ${ }^{1}$ and José C.V. Rodrigues ${ }^{2}$ \\ ${ }^{1}$ Lab. Quarentena Vegetal, Embrapa Recursos Genéticos e Biotecnologia, C. postal 02372, 70.770-900, Brasília, DF \\ Brazil,leticia@cenargen.embrapa.br,navia@cenargen.embrapa.br \\ ${ }^{2}$ Crop Protection Dept., Univ. Puerto Rico, College of Agricultural Sciences, HC - 04 Box 7115, Juana Diaz, PR 00795 \\ USA, jose_carlos@mac.com; working at that time at Centro de Biotecnologia da Amazônia-CBA, Manaus, AM, Brazil
}

Neotropical Entomology 36(4):587-592 (2007)

Ácaros Brevipalpus Donnadieu (Prostigmata: Tenuipalpidae) Associados a Plantas Ornamentais no Distrito Federal

RESUMO - Os ácaros do gênero Brevipalpus colonizam um grande número de espécies frutíferas e ornamentais e têm sido associados a viroses de muitas plantas. A leprose dos citros é a virose de maior importância econômica transmitida por esses ácaros. Recentemente foi comprovado que algumas plantas ornamentais podem ser hospedeiras alternativas desse vírus. Os grandes volumes e a alta movimentação das plantas ornamentais fazem com que estas ajam como eficientes disseminadoras de pragas. Por essa razão, é necessário ampliar o conhecimento sobre pragas potenciais, de modo a subsidiar a implementação de medidas quarentenárias. Neste trabalho são relatadas as plantas ornamentais hospedeiras de ácaros Brevipalpus no Distrito Federal, assim como a ocorrência de sintomas típicos de viroses a elas transmitidas por Brevipalpus. Entre julho e setembro de 2005, foram realizadas cinco coletas em 14 localidades do DF. Foram amostradas folhas e ramos de 55 espécies de ornamentais. Pithecellobium avaremotemo Mart. é relatada, pela primeira vez, como hospedeira das espécies $B$. phoenicis (Geijskes), B. californicus Banks e B. obovatus Donnadieu. Adicionalmente, são relatadas sete novas espécies como hospedeiras de Brevipalpus na América do Sul. Novos hospedeiros são também listados para cada uma das espécies. Sintomas típicos de viroses transmitidas por Brevipalpus foram observados em Ligustrum sinense Lour., Pelargonium hortorum L.H. Bailey, Hibiscus rosa-sinensis L. e orquídeas (Dendrobium e Oncidium). Os resultados deste trabalho enfatizam o papel potencial de plantas ornamentais como veículo para disseminação de ácaros Brevipalpus.

PALAVRAS-CHAVE: Acari, fitófago, ácaro plano, virose transmitida, fitovirose, sanidade vegetal

ABSTRACT - Brevipalpus mites colonize a great number of fruit and ornamental plants. Mite species belonging to this genus have been associated with many plant viruses. Citrus leprosis (CiLV) is the most economically important virus transmitted by B. phoenicis mites. It has recently been shown that ornamental plant species can be alternative hosts of this virus. The high volume of trade and frequent movement of live ornamental plants make them efficient pest disseminators. Because of this, it is desirable to expand knowledge of potential pests aiming to guide the adoption of quarantine measures. This work reports ornamental plant hosts of Brevipalpus mites in the Distrito Federal (DF), as well the occurrence of symptoms consistent with Brevipalpus-borne plant viruses in these same hosts. Between July and September of 2005, five surveys were carried out in 14 localities within DF. Leaves and branches of fifty-five ornamental plant species were sampled. The species Pithecellobium avaremotemo Mart. is for the first time reported as a host for B. phoenicis (Geijskes), B. californicus Banks and B. obovatus Donnadieu species. Additionally, seven new species are reported as hosts for Brevipalpus within South America. New hosts are also listed for individual mite species. Typical symptoms of Brevipalpus-borne viruses were observed in Ligustrum sinense Lour., Pelargonium hortorum L.H. Bailey, Hibiscus rosasinensis L. and orchids (Dendrobium and Oncidium). The results of this work emphasize the potential role of the ornamental plants as vehicles for dissemination of Brevipalpus mites.

KEY WORDS: Acari, phytophagous, flat mite, mite-borne virus, plant health 
Many phytophagous mite species can assume pest status. Among them, emergent importance is assigned to species belonging to Brevipalpus Donnadieu. The most frequently reported species in this genus are B. californicus (Banks), $B$. obovatus Donnadieu, and B. phoenicis (Geijskes) (Childers et al.2003a). These mites have a great number of hosts, including fruits, ornamentals, and forest plants. Childers et al. (2003a) reported 928 hosts in 513 genera and 139 families. The main damages associated with Brevipalpus mites are indirect; they are listed as vectors of plant viruses (Childers et al. 2003b). The most important Brevipalpus-associated viruses are Citrus Leprosis Virus (CiLV) (Rodrigues et al. 2003), Coffee Ringspot Virus (CoRSV) (Chagas et al. 2003), the Passion Fruit Green Spot Virus (PGSV) (Kitajima et al. 2003b), Ligustrum Ringspot Virus (LiGSV) (Rodrigues \& Nogueira 1996) and Orchid fleck virus (OFV) (Kondo et al. 2003). Symptoms of viruses transmitted by Brevipalpus have been reported in eleven ornamental plant genera: Brunfelsia, Clerodendron, Pelargonium, Hedera, Hibiscus, Malvaviscus, Pelargonium, Schefflera, Solanum, Thunbergia and Viola (Kitajima et al. 2003a, Nogueira et al. 2003, Rodrigues et al. 2005).

The ornamental plant industry in Brazil has grown substantially in recent years (Coutinho 2001). High volume and rapid trade of these plants facilitate efficient pest dissemination. According to Childers \& Rodrigues (2005), the introduction of ornamental plants from countries where citrus leprosis and related Brevipalpus-borne viruses occur magnifies the risk of spread of these viruses to new areas. In a similar way, the domestic trade of ornamental plants in a country as large as Brazil could lead to the spread of diseases or pests that were previously restricted in distribution. Therefore, it is extremely important to know the pests and diseases associated with ornamental plants so that appropriate quarantine measures can be adopted to limit their spread. Distrito Federal (DF) was of special interest because of the successful and expanding ornamental plant industry located there (Agência Sebrae de Notícias 2005).

The objectives of this work were to identify the ornamental plants that are hosts of Brevipalpus mites in the Distrito Federal (DF) and to identify potential Brevipalpusborne viruses associated with infestations of these mites. We report new hosts for Brevipalpus mites and present evidence of Brevipalpus-borne viruses in ornamental plants found in the DF.

\section{Material and Methods}

Ornamental plants commonly grown in the DF and those listed as Brevipalpus hosts in Childers et al. (2003a) were primarily inspected. Five surveys were carried out between July and September of 2005 (29/VII, 15/VIII, 26/VIII, 06/IX, and $13 / \mathrm{IX})$ in 14 localities of the DF, mainly nurseries and parks, resulting in 85 samples from 55 plant species (Table 1).

Samples consisted of twigs, old and new leaves collected from the inside and the outside of the canopy, according to the architecture of the plant. Each sample was placed in a paper bag which in turn was placed inside of a plastic bag. The bags were conditioned in an insulated box with ice packets and transported to the Laboratório de Quarentena
Vegetal - LQV, Embrapa Recursos Genéticos e Biotecnologia (EMBRAPA CENARGEN), where they were stored at $5^{\circ} \mathrm{C}$ until processed within two days. Samples were inspected under a stereomicroscope (Olympus DF PLFL) at 50x magnification and then washed in a solution of commercial detergent (5-10\%). The solution was filtered using two overlapping sieves (16 Mesh; 270 Mesh). The larger sieve retained debris and the other retained the mites, which were then washed with $70 \%$ ethanol into a Petri dish. The ethanol solution was inspected under the stereomicroscope $(50 \mathrm{x})$. All mites of the Tenuipalpidae family were slide mounted in Hoyer's medium. They were identified to species using an optic microscope with phase contrast (Olympus BX 51) and using as reference Welbourn et al. (2003). The specimens were deposited in the Mite Reference Collection for the Biological Security, LQV, Embrapa Recursos Genéticos e Biotecnologia (EMBRAPA CENARGEN).

The plants from which samples were taken for mite screening were also visually inspected for symptoms of disease consistent with Brevipalpus-borne viruses as reported by Kitajima et al. (2003a). Symptomatic plant tissues were collected in fixative for electron microscopic analysis Kitajima et al. (2003a).

\section{Results and Discussion}

Brevipalpus mites were found in 33 of the 55 ornamental plant species sampled in the DF (Table 1). Three species were represented - $B$. californicus, B. phoenicis and $B$. obovatus. These three species of Brevipalpus are the most commonly found in Brazil and are of economic importance worldwide (Childers \& Derrick 2003). B. phoenicis was the most frequent species found (Table 1). This result is in accordance with the information given by Childers et al. (2003a) on the large number of plant species hosting this mite. Twelve plant species were infested by more than one species of Brevipalpus (Table 1). The concurrent occurrence of different Brevipalpus species on each host plants supports previous reports (Childers et al. 2003a) and indicates that this is not a rare phenomenon (in this case 12 of 33 plant species). On four of the ornamental plant species (Heliconia sp., Euphorbia pulcherrima Willd. Ex Klotzsch, Philodendron bipinnatifidum Schott and Syngonium angustatum Schott) only immature Brevipalpus individuals were found, and these could not be identified to species. On those plants nothing can be said on the possible concurrence of more than one species.

Although this work was not designed to quantify the mite infestations, highest densities of Brevipalpus were observed on Acalypha wilkesiana Müll. Arg. (Euphorbiaceae), Allamanda cathartica L. (Apocynaceae), Hibiscus rosa-sinensis L. (Malvaceae), Justicia brandegeana Wassh. \& L.B.Sm. (Acanthaceae), Pyrostegia venusta Miers (Bignoniaceae), Schefflera actinophylla (Endl.) Harms (Araliaceae) and Tecoma stans (L.) H.B. \& K. (Bignoniaceae).

Symptoms consistent with Brevipalpus-borne virus infection were observed in Ligustrum sinense Lour., Pelargonium sp., H. rosa-sinensis and orchids (Dendrobium sp. and Oncidium sp.). Symptomatic tissues of these plants 
Table 1. Ornamental plants sampled for Brevipalpus mites between July and September 2005, in 15 localities in Distrito Federal, Brazil. Collecting Date: 1. 29.VII; 2. 15.VIII; 3. 26.VIII; 4. 06.IX e 5. 13.IX. Collecting Places: a. Nursery INovacap; b. Parque Sarah Kubitschek/setor Sudoeste; c. Estacionamento da Torre de TV; d. Setor de Indústrias Gráficas; e. SQN 313 BL H; f. Escola SQN 115; g. SQN 115 BL F; h. SQN 115 BL G; i. SQN 315 BL E; j. SQN 315 BL G; k. SQN 315 BL K; 1. Nursery Central Flores; m. Nursery II-Novacap; n. Nursery Pau Brasília.

\begin{tabular}{|c|c|c|c|}
\hline Families and plant species & Brevipalpus species & Collecting & New reports \\
\hline \multicolumn{4}{|l|}{ Acanthaceae } \\
\hline \multicolumn{2}{|l|}{ Hemigraphis alternata T. Anders. } & \multicolumn{2}{|l|}{ 1.a, 4.a } \\
\hline Justicia brandegeana Wassh. \& L.B.Sm. & B. phoenicis & \multicolumn{2}{|l|}{$3 . \mathrm{g}$} \\
\hline \multicolumn{2}{|l|}{ Thunbergia mysorensis T. Anders. ex Bedd. } & \multicolumn{2}{|l|}{$5 . \mathrm{n}$} \\
\hline \multicolumn{4}{|l|}{ Agavaceae } \\
\hline Cordyline terminalis Kunth & B. obovatus, B. phoenicis & 1.a, 2.e, 3.i & $* *, * * \mathrm{Bp},{ }^{* \mathrm{Bo}}$ \\
\hline \multicolumn{4}{|l|}{ Apocynaceae } \\
\hline Allamanda cathartica L. & B. phoenicis & 1.a, 2.c & $* *, * * \mathrm{Bp}$ \\
\hline Nerium oleander L. & & \multicolumn{2}{|l|}{ 1.a, $2 . d$} \\
\hline Trachelospermum jasminoides Lem. & B. phoenicis & \multicolumn{2}{|l|}{$5 . n$} \\
\hline \multicolumn{4}{|l|}{ Araceae } \\
\hline Anthurium andraeanum Linden. & & \multicolumn{2}{|l|}{$3 . g$} \\
\hline Philodendron bipinnatifidum Schott. & Brevipalpus sp. & \multicolumn{2}{|l|}{ 3.h } \\
\hline Syngonium angustatum Schott. & Brevipalpus sp. & \multicolumn{2}{|l|}{$3 . \mathrm{i}$} \\
\hline \multicolumn{4}{|l|}{ Araliaceae } \\
\hline Polyscias guilfoylei L.H. Bailey & B. obovatus, B. phoenicis & 2.e & $* *, * * \mathrm{Bp}, * \mathrm{Bo}$ \\
\hline Schefflera actinophylla (Endl.) Harms & B. phoenicis & \multicolumn{2}{|l|}{$3 . g, 5 . n$} \\
\hline Schefflera arboricola (Hayata) Merr. & B. californicus, B. phoenicis & 1.a, 3.h & $* *, * \mathrm{Bp}, * \mathrm{Bc}$ \\
\hline \multicolumn{4}{|l|}{ Asclepiadaceae } \\
\hline Impatiens walleriana Hook.f. & & \multicolumn{2}{|l|}{ 1.a, $4 . \mathrm{a}$} \\
\hline \multicolumn{4}{|l|}{ Asteraceae } \\
\hline Tagetes erecta L. & & \multicolumn{2}{|l|}{ 1.a } \\
\hline Zinnia sp. & & \multicolumn{2}{|l|}{ 1.a } \\
\hline
\end{tabular}

Bignoniaceae

$\begin{array}{llll}\text { Pyrostegia venusta } \text { Miers } & \text { B. phoenicis } & 5 . \mathrm{n} & * *, * *^{\mathrm{Bp}} \\ \text { Tabebuia } \text { sp. } & & 4 . \mathrm{m} & \\ \text { Tecoma stans (L.) H.B. \& K. } & \text { B. obovatus, B. phoenicis } & 1 . \mathrm{a}, 2 . \mathrm{b} & * *, *^{\mathrm{Bp}}, *^{\mathrm{Bo}} \\ \text { Bombacaceae } & & \\ \text { Pachira aquatica Aubl. } & & 4 . \mathrm{m}\end{array}$

Bromeliaceae
Gusmania sp.
B. phoenicis
$5 . n$

Buxaceae
Buxus sempervirens L.
B. phoenicis
$5 . n$

Cannaceae

Canna sp.

1.a, $4 . \mathrm{a}$

Caprifoliaceae 
Table 1. Continuation.

\begin{tabular}{|c|c|c|c|}
\hline Families and plant species & Brevipalpus species & Collecting & New reports \\
\hline Viburnum suspensum Lindl. & & 4.a & \\
\hline \multicolumn{4}{|l|}{ Compositae } \\
\hline Dahlia sp. & & 2.d & \\
\hline \multicolumn{4}{|l|}{ Dracaenaceae } \\
\hline Dracaena fragrans Ker. Gawl. & & 3.1 & \\
\hline Dracaena marginata Horne ex Baker & B. phoenicis & 1.a, 2.e, 3.i & \\
\hline
\end{tabular}

Euphorbiaceae

Acalypha wilkesiana Müll. Arg. B. californicus, B. obovatus, B. phoenicis 1.

Breynia nivosa Small $\quad 5 . n$

$\begin{array}{lll}\text { Codiaeum variegatum (L.) A. Juss. } \quad \text { B. phoenicis } & \text { 2.e, 3.k }\end{array}$

Euphorbia pulcherrima Willd. ex Klotzsch Brevipalpus sp. 2.d, 3.j

Lamiaceae
Gmelina arborea Roxb.
B. obovatus, B. phoenicis
4.m
Salvia farinacea Benth.
2.d

Leguminosae

Bauhinia variegata L.

B. phoenicis

2.b, 3.f, $4 . \mathrm{m}$

Cassia sp.

4.m

Delonix regia Raf.

4.m

Magnoliaceae

Michelia champaca L.

B. phoenicis

4.m

Malvaceae

Hibiscus rosa-sinensis L.

Malvaviscus arboreus Cav.

B. obovatus, B. phoenicis

B. obovatus, B. phoenicis

2.e

1.a, 4.a

Mimosaceae

Pithecellobium avaremotemo Mart.

B. phoenicis

4.m

1.a, 4.a, 2.e

Tibouchina sp.

Musaceae

Heliconia sp.

B. phoenicis

$5 . n$

Nyctaginaceae

Bougainvillea sp.

Brevipalpus sp.

B. phoenicis

1.a, 2.b, 3.j

Oleaceae

Ligustrum sinense Lour.

Ligustrum sp. L.

B. obovatus, B. phoenicis

1.a, 2.e

$4 . \mathrm{m}$

Portulacaceae

Portulaca oleracea L.

Primulaceae

Grevillea banksii R.Br.

B. obovatus, B. phoenicis

$*^{\mathrm{Bo}}, *^{\mathrm{Bc}}$

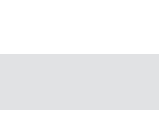


Table 1. Continuation.

\begin{tabular}{|c|c|c|c|}
\hline Families and plant species & Brevipalpus species & Collecting & New reports \\
\hline Punica granatum L. & B. obovatus & $3.1,4 . \mathrm{m}$ & \\
\hline \multicolumn{4}{|l|}{ Rubiaceae } \\
\hline Ixora sp. & & $5 . \mathrm{n}$ & \\
\hline \multicolumn{4}{|l|}{ Solanaceae } \\
\hline Brunfelsia uniflora D. Don & B. obovatus, B. phoenicis & $5 . \mathrm{n}$ & $*$ Bo \\
\hline Cestrum nocturnum L. & B. phoenicis & 3.1, 3.g & \\
\hline \multicolumn{4}{|l|}{ Sterculiaceae } \\
\hline Guazuma crinita Mart. & & $4 . \mathrm{m}$ & \\
\hline \multicolumn{4}{|l|}{ Theaceae } \\
\hline Camellia japonica Champ. & & $5 . \mathrm{n}$ & \\
\hline \multicolumn{4}{|l|}{ Verbenaceae } \\
\hline Lantana camara L. & B. phoenicis & 1.a, 4.a & \\
\hline \multicolumn{4}{|l|}{ Zingiberaceae } \\
\hline Alpinia purpurata K. Schum. & B. obovatus, B. phoenicis & $3 . \mathrm{i}, 5 . \mathrm{n}$ & \\
\hline
\end{tabular}

New reports: $*=$ First reported as Brevipalpus host in the world; ** = First reported as Brevipalpus host in South America; $*$ Bp First reported as B. phoenicis host in the world; **Bp First reported as B. phoenicis host in South America; ${ }^{* B o}$ First reported as $B$. obovatus host in the world; **Bo First reported as B. obovatus host in South America; ${ }^{* B c}$ First reported as B. californicus host in the world.

were collected in paraformaldeid/glutaraldeid 3\% fixative and sent to Dr. E. Kitajima (University of Sao Paulo) for electronic microscopy analysis, who confirmed that viruslike particles were present in all of those plants as well as on passion fruit, Passiflora edulis Sims, not included in this study (E.W. Kitajima - personal communication).

Pithecellobium avaremotemo Mart. is for the first time listed as host of Brevipalpus mites. B. californicus had already been found infesting another species in the genus in Africa: Pithecellobium dulce Bentham (Childers et al. 2003a). The results also confirmed some of the Brevipalpus host species that had already been reported elsewhere in South America as A. cathartica, P. venusta, Cordyline terminalis Kunth, Grevillea banksii R. Br., Polyscias guilfoylei L.H. Bailey, T. stans and Schefflera arboricola (Hayata) Merr.

New hosts were identified for individual species of Brevipalpus in this study. Four new host species were found for B. phoenicis: P. avaremotemo, G. banksii, T. stans, and $S$. arboricola, and four others that were new reports for South America: A. cathartica, P. venusta, C. terminalis and P. guilfoylei.

For B. obovatus, there were six new reports: A. wilkesiana, Brunfelsia uniflora D. Don, C. terminalis, G. banksii, P. guilfoylei, and T. stans. In addition this mite was reported on H. rosa-sinensis for the first time in South America.

$B$. californicus is reported for first time on $S$. arboricola and A. wilkesiana.

Some ornamental plants had already been reported as hosts of Brevipalpus mites in South America. However, in this survey, different species were added to the list. $A$. wilkesiana hosted B. californicus and B. obovatus, and has already been reported hosting $B$. phoenicis (Childers et al. 2003). B. uniflora and $H$. rosa-sinensis are new hosts for $B$. obovatus, and previously they have been reported as hosts for B. phoenicis.

The great number of host plants of Brevipalpus mites identified in this survey of the DF indicates that there is a gap of information in relation to the host range of this group of mites. It is important to extend this knowledge, considering the high risk of the trade of ornamental plants in the dissemination of these pests and their associated viruses. It is necessary to intensify the surveys of Brevipalpus mites and associated viruses in the diverse regions of Brazil.

In addition, the capacity of different Brevipalpus species to transmit viruses has not been well studied. It is necessary to know if more than one species of Brevipalpus is involved in the transmission of citrus leprosis virus or the other related viruses. This information is imperative for the definition of strategies of control in an integrated pest management program. A limited number of morphologic traits are used to distinguish the species of Brevipalpus, and it is difficult to identify them. It has been suggested that the morphotype recognized today as $B$. phoenicis is in reality a complex of species (Gonzalez 1975, Welbourn et al. 2003, Rodrigues et al. 2004). It was also suggested that there are hybrids sharing characteristics belonging to two distinct species (Welbourn et al. 2003). A more complete knowledge of taxonomic aspects of the group is essential to guide measures to prevent the dissemination of harmful vector species that, now, are still restricted in distribution in Brazil.

Even without more detailed and thorough information it is important to organize the transit of potential Brevipalpus 
host plants between distinct regions of the country and more importantly between countries. The results of this work emphasize the potential role of the ornamental plants as vehicles for dissemination of Brevipalpus mites.

In the near future, ornamental plant growers in the DF will start to supply the domestic market with ornamental plants, and may begin exporting to other states (Agência Sebrae de Notícias 2005). Special attention should be taken with phytossanitary measures to prevent the dissemination of these mites. It is equally important to inspect and to control the batches of ornamental plants that arrive in the DF.

It is possible that Brevipalpus mites associated with ornamental plants carry the CiLV. Therefore, states where CiLV does not occur must reinforce quarantine protocols to minimize the risk of introduction of the disease. Hosts of Brevipalpus coming from states where the disease has been reported should be carefully inspected.

\section{Acknowledgments}

To E. W. Kitajima, ESALQ, USP, for electron microscopy analysis of plant material. To Companhia Urbanizadora da Nova Capital (NOVACAP) Sede - Departamento de Parques e Jardins, and to technicians of Viveiros I e II NOVACAP, Viveiro Pau Brasília and Central Flores, for the authorization and help during the collections and plant identification.

\section{References}

Agência Sebrae de Notícias. Plantas ornamentais no DF. Available in: $<$ http://asn.interjornal.com.br/site/noticia.kmf?noticia=34 46947\&canal=36>. Access 5th August, 2005.

Chagas, C.M., E.W. Kitajima \& J.C.V. Rodrigues. 2003. Coffee ringspot virus vectored by Brevipalpus phoenicis (Acari: Tenuipalpidae) in coffee. Exp. Appl. Acarol. 30: 203-213.

Childers, C.C. \& J.C.V. Rodrigues. 2005. Notes on acari species on ornamental plants from Central America imported for propagation in Florida and potential risks of exotic pest introductions. Fla. Entomol. 88: 408-414.

Childers, C.C., J.C.V. Rodrigues \& W.C. Welbourn. 2003a. Host plants of Brevipalpus californicus, B. obovatus, and B. phoenicis (Acari: Tenuipalpidae) and their potential involvement in the spread of viral diseases vectored by these mites. Exp. Appl. Acarol. 30: 29-105.

Childers, C.C., J.V. French \& J.C.V. Rodrigues. 2003b. Brevipalpus californicus, B. obovatus, B. phoenicis and B. lewisi (Acari: Tenuipalpidae): A review of their biology, feeding injury and economic importance. Exp. Appl. Acarol. 30: 5-28.
Childers, C.C. \& K.S. Derrick. 2003. Brevipalpus mites of unassigned rhabdovirus in various crops. Exp. Appl. Acarol. 30:1-3.

Coutinho, L.N. 2001. Problemas de introdução de doenças no país por meio da aquisição de plantas ornamentais exóticas. Biológico 63: 41-44.

Gonzalez, R.H. 1975. Revision of the Brevipalpus phoenicis "complex" with description of new species from Chile and Thailand (Acarina, Tenuipalpidae). Acarol. 17: 81-91.

Kitajima, E.W., C.M. Chagas \& J.C.V. Rodrigues. 2003 a. Brevipalpus-transmitted plant virus and virus like diseases: Cytopathology and reports of some recent cases. Exp. Appl. Acarol. 30: 135-160.

Kitajima, E.W., J.A.M. Resende \& J.C.V. Rodrigues. 2003b. Passion fruit green spot virus vectored by Brevipalpus phoenicis (Acari: Tenuipalpidae) on passion fruit in Brazil. Exp. Appl. Acarol. 30: 225-231.

Kondo, H., T. Maeda \& T. Tamada. 2003. Orchid fleck virus: Brevipalpus californicus mite transmission, biological properties and genome structure. Exp. Appl. Acarol. 30: 215-223.

Nogueira, N.L., J.C.V. Rodrigues \& M.L. Rossi. 2003. Partículas semelhantes a rhabdovírus em três espécies ornamentais apresentando lesões locais e presença do ácaro Brevipalpus. Summa Phytopathol. 29: 278-282.

Rodrigues, J.C.V., E.C. Locali \& J. Freitas-Astua. 2005. Transmissibility of Citrus leprosis virus by Brevipalpus phoenicis to Solanum violaefolium. Plant Dis. 89: 911.

Rodrigues, J.C.V., E.W. Kitajima, C.C. Childers \& C.M. Chagas. 2003. Citrus leprosis virus vectored by Brevipalpus phoenicis (Acari:Tenuipalpidae) in citrus in Brazil. Exp. Appl. Acarol. 30: 161-179.

Rodrigues, J.C.V., M. Gallo-Meagher, R. Ochoa, C.C. Childers \& B.J. Adams. 2004. Mitochondrial DNA and RAPD polymorphisms in the haploid mite Brevipalpus phoenicis (Acari: Tenuipalpidae). Exp. Appl. Acarol. 34: 275-290.

Rodrigues, J.C.V. \& N.L. Nogueira. 1996. Ocorrência de Brevipalpus phoenicis G. (Acari: Tenuipalpidae) em Ligustrum lucidum (Oleaceae) associado à mancha anelar do Ligustre. An. Soc. Entomol Brasil 25: 263-264.

Welbourn, W.C., R. Ochoa, E.C. Kane \& E.F. Erbe. 2003. Morphological observations on Brevipalpus phoenicis (Acari: Tenuipalpidae) including comparisons with B. californicus and B. obovatus. Exp. Appl. Acarol. 30: 107-133.

Received 02/VI/06. Accepted 06/X/06. 